\title{
ICT Pre-service Teachers' Opinions about the Contribution of Initial Teacher Training to Teaching Practice
}

\author{
Hatice Sancar Tokmak \\ Mersin University, Turkey \\ Turkan Karakus \\ Middle East Technical University, Turkey
}

\begin{abstract}
The purpose of this qualitative study is to investigate how well initial teacher training in ICT prepare pre-service teachers to teaching profession. Eight pre-service teachers attending to the "School Experience" course from the Computer Education and Instructional Technology Department at the Middle East Technical University took part in this case study. Observation and interview methods were employed to gather data. Moreover, pre-service teachers' lesson plans prepared for teaching activity were analyzed. The results showed that initial teacher training courses provided several affective teaching skills such as developing awareness about the importance of being well-prepared for each class, being calm for unexpected situations, and understanding the reasons of students' misbehaviors in the class. However, according to ICT pre-service teachers, practical aspect of these courses was not enough. Most of them stated that they could not apply different strategies in different contexts. In addition, due to the lack of experience on classroom management they had difficulty in completing subjects although they left extra time for each activity in their lesson plans.
\end{abstract}

Keywords: Teaching practice; Initial teacher training; Case study; ICT pre-service teachers.

\section{Introduction}

Initial Teacher Training (ITT) courses are important to prepare undergraduate students for their professional life. The teacher education in Information and Communication Technologies (ICT) program consists of learning, learning theories, designing instruction, teaching strategies, classroom management, material design and technology integration into instruction. According to Draper, O'Brien and Christie (2004), the initial and continuing professional development of teachers are very important for teacher training field. However, there is not a consensus on what the development program should focus on. For example, according to Freiberg (2002), the program should focus on pedagogical knowledge. On the other hand, according to Willis (2002), teaching practice should be the main concern of professional development programs.

Smaldino, Lowther and Russell (2007) emphasize the importance of knowledge on instructional theories and application of them for a specific topic, "Media Selection for Instruction". With 
respect to these views, researchers advocate that it is valuable to know pre-service teachers' challenges in classes to re-shape the design of teacher training programs which were offered to undergraduate students. Draper, Fraser, Smith and Taylor (1991) conducted a study in order to define what challenges novice teachers survived during their instruction in classes (as cited in Draper, et al., 2004). The results of the study showed that most of the new-comer teachers complained about discipline problems and they stated that classroom management was very difficult for them (Draper, Fraser, Smith \& Taylor, 1991 as cited in Draper, et. al., 2004). In line with the results of that study, Featherstone (1993) found in his study that teachers had difficulty in providing discipline in classes at the beginning of their profession. Orungbemi (2009) also found that there was a relationship between teachers' teaching skills and discipline problems in the classroom. He advocates that discipline problems such as undesirable noise in classrooms stem from boredom and inattentiveness of pupils during instruction and effective teaching can help to reduce such discipline problems (Orungbemi, 2009). The literature consensuses on that teacher training programs have mission of providing affective teaching skills for pre-service teachers.

The reasons and solutions of the mentioned problems which the novice teachers survived in their profession has been tried to be answered for years. Korthagen and Kessels (1999) criticize the initial teacher training programs including traditional theory based applications more than practice which provides quick decision making by considering context and available situations. According to Trigwell, Prosser and Waterhouse (1999), teaching approaches that have been used by teachers should be chosen with respect to learners' learning approaches. In addition, Mellado (1998) advocates that educators working on initial teacher training programs to consider transfer of knowledge from theory to practice by taking pre-service teachers' beliefs and values about teaching into account. Loughran and Northfield (1998) state that complexity of teaching, classroom dynamics, school contexts, and people's beliefs and experiences could be understood in real context rather than in artificial ones.

In line with the need revealed by the literature review, there were two aims of this study: (1) to investigate ICT pre-service teachers' opinions about how well theoretical background of initial teacher training courses prepares them to their profession; (2) how well these courses provide practical skills for ICT pre-service teachers. To understand pre-service teachers' background knowledge and skills, they were interviewed. The data were collected through one semester when they took the "School Experience" course. Pre-service teachers observe mentor teachers at work, observe students during instruction and outside, and teach in one class on scope of "School Experience" course. This provides pre-service teachers an opportunity to observe authentic teaching and to enter into real school life. The study examined the contributions of initial teaching courses to pre-service teachers' practices in their point of view. Main research questions of the present study were:

1. What do the ICT pre-service teachers think about the practical value of the initial teacher training courses?

1.1. What do the ICT pre-service teachers think about which practical skills that they used during their instruction coming from initial teacher training courses?

1.2. Which problems do the ICT pre-service teachers experienced while they are teaching in real context? 
1.3. What are the suggestions of the ICT pre-service teachers to improve practical aspects of initial teacher training courses?

\section{Methodology}

According to Maxwell (1996), there are five particular research purposes that qualitative studies are suited, namely, "understanding the meaning", "understanding the particular context", "understanding unexpected phenomena and influences to generate new grounded theories", "understanding the process", and "developing causal explanations". With this respect, this qualitative research study aimed to understand background of pre-service teachers and to "develop causal explanations" for their practice skills. The single case research design was followed to accomplish the purposes of this study which was described as "....a detailed examination of one setting, or a single subject, a single depository of documents, or a particular events" (Bogdan \& Biklen, 1998, p.59). Main data collection methods were the classroom observations and individual interviews.

\section{Context}

In the "School Experience" course, students went to a private school to observe mentor teachers as well as students and teach in real context. This private school for ICT students was selected specifically because the ICT students wanted not to experience problems related with the infrastructure. The private school had two computer laboratories and four computer teachers. Moreover, all the computers could be controlled by teacher because the computers had two mode as $A$ and $B$. Whenever teacher wanted to control students' computers, s/he chose B mode. The laboratories were placed in the opposite side of a corridor and have similar looking in terms of structure, equipments and the orderings of desks. Each laboratory had a video-projector and 30 computers. The computer desks were arranged in U-shape as shown in the Figure 1.

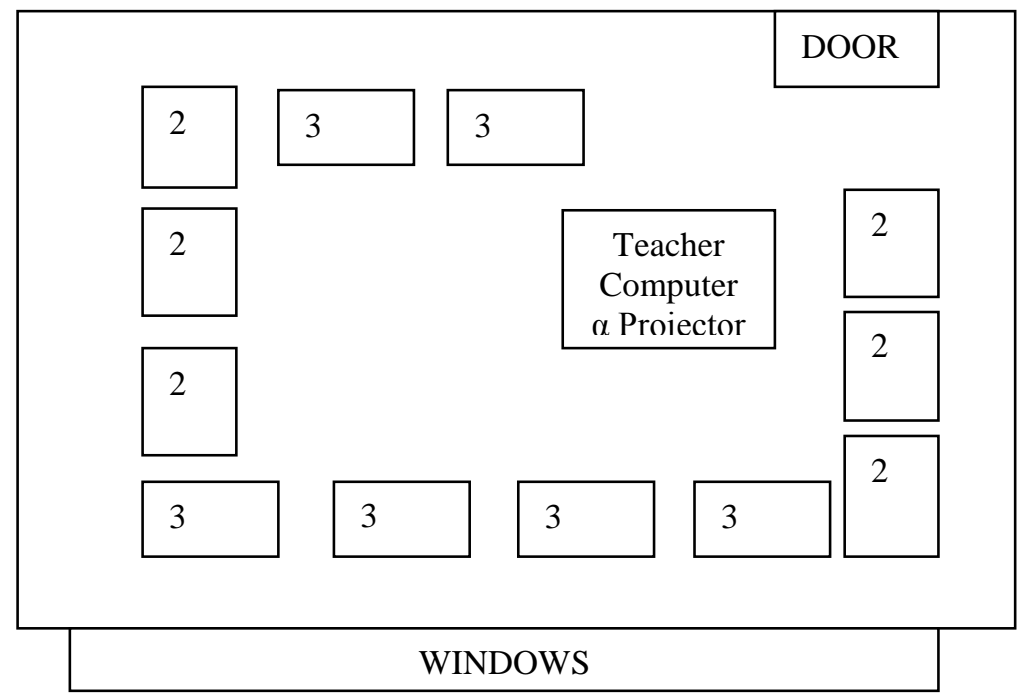

Figure 1. The Structure of the Computer Laboratories that Pre-service Teachers Taught 


\section{Participants}

Sampling strategy of a research study shows the quality of the inferences made by researcher and for that reason it is one of the important steps in research studies (Collins, Onwuegbuzie \& Jiao, 2006). The researcher was aware of this importance and in line with the aim of the study; she followed one of the qualitative sampling procedures, Complete Collection (Criterion Sampling). One of the criteria was that teacher candidates should take the entire initial teacher training courses to investigate their opinions about the practical value of educational courses. Second criterion was that they should be observed while they were teaching in real context in order to provide them to realize whether they can apply what they learn or not. For that reason, senior $\left(4^{\text {th }}\right.$ year) ICT students were chosen as participants in the study.

There were 42 senior ICT students in the department. Since the students had to go to schools and teach under the scope of "School Experience" courses, the "School Experience" course instructors wanted course assistants to deal with each student personally. For that reason, the ICT students were grouped into 5. Each group consisted of 8 or 9 students. 8 volunteer students from these groups participated to the study. One of the students who participated to the study from Tasmania but since he was student at the ICT program at the beginning of his university life (from $1^{\text {st }}$ year to $4^{\text {th }}$ year), the researchers decided that his participation would not affect the study results. Four of the participants were females while 4 of them were males. The participants' ages ranged from 23 to 26 .

\section{Instrumentation}

The interview form was prepared by researchers and checked by an expert. The form was modified according to expert opinion and this modified version was used to be interviewed with two people who were not from the education field to see whether the questions were understood even by people who do not know anything about the content. After very small changes, the second version was checked by the expert and the expert stated that it could be conducted as it. So, the second version of the form was used during the study. The form included questions about contribution of ITT courses to pre-service teachers' teaching practice. Specifically, satisfaction with ITT courses, effectiveness of these courses, use of theoretical knowledge in their practice, and their suggestions on content as well as methods of these courses were inquired.

The observation form was also developed by the researchers. This form was based on the observation form used by "School Experience" course instructors to observe pre-service teachers while they are teaching in classes. A few items in the observation form about the "Planning of Instruction" were eliminated. This version was checked by an expert and the ordering of the items was changed according to his opinion. Then this version was applied during the study. They observed the pre-service teachers in terms of lecturing skills, preparation for challenges of real classroom, skills of providing student participation and classroom management while they were teaching in real schools. The observation form was consisted of 4 main parts, namely, contextual issues, classroom management, instructional issues and student interaction. Two researchers observed the classes at the same time. 


\section{Procedures}

The pre-service teachers were first observed by two researchers while they were teaching $4^{\text {th }}$ grade elementary school students under the scope of "School Experience" course. They have to take in last semester of their training and go to elementary schools for 6 hours in a week. They also teach at one session in the semester. The researchers observed them in their teaching session and then conducted interviews after their teaching experience. Each pre-service teacher was observed about two hours and interviewed with about 30 minutes. The interview sessions were recorded with a tape recorder. Observation notes were used to support how pre-service teachers transfer their theoretical knowledge into real classroom context. Interview and observation records were transcribed and coded by both researchers. The interview inter-rater reliability was calculated as .76 according to Miles and Huberman's (1984) formula. The results were presented in a narrative way after researchers discussed on their findings.

\section{Results}

To analyze data, they were first transcribed. The transcribed data were analyzed by using open coding method. According to the analysis results, five main categories merged. These categories were grouped in seven main titles which are changes in opinions about teaching profession after taking ITT courses, the skills that a teacher should have, the necessity of ITT courses, the contributions of ITT courses to improve pre-service teachers' teaching skill, problems in ITT courses, problems faced during teaching, suggestions for ITT courses. The main categories and related sub categories were shown the Table 1.

Table 1. Main and Sub Categories According to the Results of Data Analysis

\begin{tabular}{l|l}
\hline Main Categories & Sub-Categories \\
\hline $\begin{array}{l}\text { Changes in opinions about } \\
\text { teaching profession after taking } \\
\text { ITT courses }\end{array}$ & $\begin{array}{l}\text { No change in point of view of being teacher } \\
\text { Observing change in others' point of view of being teacher } \\
\text { The effects of instructors, friends and ITT courses } \\
\text { Role of "School Experience" course in changes toward teaching } \\
\text { Mentor teacher effect } \\
\text { Learning the profession after working as a teacher }\end{array}$ \\
The skills that a teacher should & Endowment \\
have & Improving themselves \\
& Loving the profession \\
& Desire to teach \\
& Self- confident \\
& Expertise on subject matter \\
& Well-preparedness \\
& Management skills \\
& B plans for lesson flow \\
& Being calm \\
\hline
\end{tabular}


Table 1. Continued

\begin{tabular}{|c|c|}
\hline Main Categories & Sub-Categories \\
\hline & $\begin{array}{l}\text { Being model for students } \\
\text { Open to educational innovations } \\
\text { Knowing child development } \\
\text { Communication skills }\end{array}$ \\
\hline The necessity of ITT courses & $\begin{array}{l}\text { Necessity } \\
\text { Improvement in teaching skills } \\
\text { Learning importance of being good model for children } \\
\text { Providing theoretical knowledge } \\
\text { Improvement in classroom management skills }\end{array}$ \\
\hline $\begin{array}{l}\text { The contributions of ITT courses to } \\
\text { improve pre-service teachers' teaching } \\
\text { skills }\end{array}$ & $\begin{array}{l}\text { Technology } \\
\text { Teaching skills } \\
\text { Lecturing skills } \\
\text { Tacit knowledge } \\
\text { Explicit knowledge } \\
\text { Instructional theories } \\
\text { Learning theories } \\
\text { Theoretical knowledge } \\
\text { Material design } \\
\text { Management skills Communication skills with students }\end{array}$ \\
\hline Problems in ITT courses & $\begin{array}{l}\text { Lack of knowledge of subject matter } \\
\text { Problem of foreign language } \\
\text { Lack of practical applications } \\
\text { Insufficiency in technical side } \\
\text { Not focusing on an issue in practice lesson } \\
\text { Activities }\end{array}$ \\
\hline Problems faced during teaching & $\begin{array}{l}\text { Unpredictability } \\
\text { Strictness of curriculum } \\
\text { Crowded classrooms } \\
\text { Time management } \\
\text { Classroom management } \\
\text { Students' not pre-preparing the lessons } \\
\text { Technical problems }\end{array}$ \\
\hline Suggestions for ITT courses & $\begin{array}{l}\text { Need more practical activities } \\
\text { Courses' languages being turned English to Turkish } \\
\text { Giving examples by thinking Turkish context } \\
\text { School Experience course's being 3rd /4th grade program } \\
\text { Practicing more in real context } \\
\text { Practicing in both public and private schools } \\
\text { Increasing instructional courses hours } \\
\text { More extracurricular activities }\end{array}$ \\
\hline
\end{tabular}




\section{Changes in Opinions about Teaching Profession after Taking ITT Courses}

In Turkey, all the students have to take University Entrance Exam to enter the university. This exam is conducted by an institution, the Student Selection and Placement Center every year. The students choose their programs and universities by taking into account their University Entrance Exam scores. The researcher asked the interviewees their reasons to enter the ICT program since if they enter the program willingness, it might affect their opinions about teaching profession. Moreover, ITT courses might cause changes in their opinions about the situation.

Six interviewees stated that initial teacher training did not cause changes in their attitudes towards being a teacher. All of them emphasized that they have always wanted to be a teacher. However, two interviewees responded that their perspective of being a teacher changed during the university education. They stated that with the effect of their instructors, friends and the educational courses they were encouraged to be a teacher although they did not when they entered the university. Besides, all interviewees justified that they observed a change in most of their friends' perspective of being a teacher during the university life because of ITT courses. One of the interviewee said that:

"My perspective on being a teacher has not changed because I have wanted to be a teacher since my childhood. But, most of the friends in our class said that they did not want to be a teacher at the preliminary years of their education. Now, I can say that most of these friends' perspective towards to be a teacher changed and courses on teaching has an important role in these changes."

According to interviewees, "School Experience" course had an important role in these changes as well as previous ITT courses. They acknowledged that they were introduced to mentor teachers thanks to "School Experience" course. They learnt many things about the profession from these mentor teachers. They pointed out that they took the mentor teachers as a model. They also could observe the mentor teachers' some wrong applications in classes. They pointed out that they paid attention to what they should not have done in classes. One of the interviewees exemplified this issue by stating,

"Mentor teacher did not control students, one day he left classroom with me...and I provided authority, towards the end of lesson, he came to classroom and he was surprised with the calmness of the classroom."

Observing mentor teachers provided pre-service teachers to gain experience on how they could tackle with classroom management problems. Also, they reported that they had chance to see real school environment and teach pupils under the scope of "School Experience" course.

\section{Skills that a Teacher Should Have}

To understand the interviewees' opinions about what kind of skills that teachers should have was one of the important questions for this study since the researchers wanted to deeply understand 
whether the ITT courses help ICT pre-service teachers improve skills mentioned by them. All interviewees stated that teaching is an endowment although teaching skills can be gained in time. They believed that the teachers can improve their professions if they desire to teach. According to interviewees, a teacher should love his/her profession at first. Moreover, they pointed out that self-confidence, being expert on a subject matter, preparedness for lessons were important for an effective instruction. Classroom management skills like being ready for problems, having a B plan for lesson flow, being calm in an unexpected situation and providing authority were critical issues emphasized by the interviewees. They also indicated that a teacher should be a good model for students. One interviewee stated that,

"When a teacher plays football, students will think that playing football is a good behavior".

According to interviewees, teachers should also be open to innovations related to their profession. They said that teachers should always improve themselves in terms of subject matter knowledge, pedagogical skills and classroom management. They also stated the importance of that a teacher knows about children development, provides motivation for her/his students in order to establish good communications with them.

\section{The Necessity of ITT Courses}

The researchers asked the interviewees what they thought about the necessity of ITT courses. According to all the interviewees, ITT courses were necessary for pre-service teachers. They stated that these courses help pre-service teachers improve teaching skills. Moreover, the interviewees pointed out that ITT courses were needed to learn about the theoretical knowledge on human learning, instruction, classroom management. One of the interviewees said that;

"I think that ITT courses were very necessary to learn about teaching and classroom management methods. Moreover, I did not know anything about the human learning or instructional theories before taking ITT courses."

Moreover, the interviewees emphasized that they learnt the importance of being a good model for students. They stated that when they entered the program, they did not think that their behaviors might also be modeled by children. According to interviewees, especially, after starting internship, they realized children take as model school teachers.

\section{The Contributions of ITT Courses to Improve Pre-service Teachers' Teaching Skills}

Six interviewees were asked about whether ITT courses help pre-service teachers improve teaching skills. They answered this question by pointing out that ITT courses help them improve teaching skills related to cognitive, psychomotor and affective domains. According to them, they know about theoretical aspect of teaching profession thanks to ITT courses. Moreover, they stated that they learnt how they could use their mimics and body language during instructions with the help of ITT courses. Some interviewees stated that they had affective attachment to teaching profession during the university life because of the instructors and ITT courses. On the other hand, 
two interviewees pointed out that there were not any contributions of ITT courses except theoretical knowledge.

Five interviewees mentioned the positive contributions of "School Experience" course as providing teaching practice opportunity for them. However, other three criticized the course because they were practicing in private schools and these schools were serving many opportunities to their students. These interviewees stated that this school had special physics, chemistry, computer, art laboratories for students; in each class there were computers for the teachers; classrooms were clean; the schoolyard was well-arranged. On the other hand, they pointed out that during their profession, they would teach in public schools where there were not these good conditions. Therefore, they believed that they were not practicing a real context. They had worries about whether their experiences prepared them public school conditions.

\section{Problems in ITT Courses}

The interviewees answered the question about the problems in ITT courses by saying that the courses focusing on theoretical aspect of learning and teaching did not contribute their professional development as much as they expected. Six interviewees stated that most of these courses did not provide them practical application of theories although they pointed out that these courses provided knowledge about instructional and learning theories as well as a motivation to be teacher. They stated that they were aware of the importance of learning and instructional theories thanks to these theoretical courses. However, according to them, casebased approaches should have been used much more in these courses. They stated that they were active during the courses in which case-based design applied. Three interviewees gave "classroom management" course as an example of these courses and they stated that they worked on cases while taking this course. One of them said that;

"Until we had taken classroom management course, we have not experienced practical applications of theories and approaches, by means of these practices I understood what the teaching looks like".

\section{Problems Faced During Practicing}

All the interviewees stated that they got opportunity to teach and observe students, mentor teachers in classes thanks to the "School Experience" course. Therefore, according to them, they could understand students, communicate with them and gain more experience on classroom management. On the other hand, they encountered several problems. These problems were mainly unpredictability, strictness of curriculum, crowded classrooms, time management, classroom management, students' not pre-preparing the lessons, technical problems.

The interviewees pointed out that they prepared several materials for their lecturing hours, and they could apply them in a real classroom. Thus, teaching practice activity provided experience for them about how they should have been prepared for a lesson. Observations showed that they gave too much importance to develop different kind of materials. On the other hand, they ignored 
the time management in that case. For example, one of the pre-service teachers made students watch several videos in 35 minutes and write a reflection on what they learnt from the videos. The actual topic was typing in Office Word and students had just 5 minutes to write their reflections. Some of students objected to write because they got bored from videos which were related to Tanzania. Similarly, another pre-service teacher who lectured about MS Office Publisher spent most of time by showing examples of posters. While showing the posters she focused on the problems of some posters. She showed a video related to the topic. She wanted students prepare a poster about that topic. By means of this practice, they noticed that they had time management problems.

The interviewees stated that they had a chance to realize a lot of problems arose both in and out of classroom (in the break time). They emphasized that classroom was an unpredictable environment. Most of time, they had to change their lesson plans. They also complained about the strictness of curriculum since it reduced the effectiveness of their teaching activities. According to them, the content of the lessons were full of textual information and the lesson time was not enough to teach all of them with different activities. They stated that for that reason, they could not deal with students, just tried to finish to content by explaining them orally. The interviewees also complained about crowded classrooms because they had difficulty in classroom management problems in those classrooms. In fact, the classrooms were not as crowded as public school classrooms. Yet, the interviewees could not manage the problems in the classroom. They reported that due to crowded classrooms, they could not deal with each student individually. Thus, some students who missed any step of the classroom activity started to talk to other students while waiting for the teacher, and this caused noise problems.

In observations, researchers noted three main points related to pre-service teachers' teaching skills. First of all pre-service teachers tended to use Gagne's Nine Events of Instruction which was very easy to implement for most of the topics. However, they spent more time while taking attention. While taking attention, they used daily life examples; they asked students their own experiences. They started to instruction by lecturing. All of them used PowerPoint presentations during the instruction. Moreover, they asked questions to students in order to take their attention and allow them to be active rather than being passive listeners. However, all of them tended to give right answers immediately when any student did not give right answer. This prevented students from thinking on the questions asked enough. Another problem during teaching sessions, the pre-service teachers did not change the lesson flow in accordance with the students' reactions. For example, one of them continued to show a video although he realized students got bored. Similarly, another pre-service teacher ignored what the students asked to him and he continued to ask his own questions to the students. The interview results showed that 6 of the 8 interviewees stated that they had difficulty in changing the instructional plan according to the students' reactions.

Observations showed that the pre-service teachers used many different materials, especially colored ones such as posters, pictures, videos and colorful PowerPoint presentations. At the end of lessons, they used discussion and summarization methods. Pre-service teachers tried to be tolerant at first. For example, if some students made noises, they did not warn them but asked questions or they gave these students some responsibilities during the instruction. However, if the noise continued long time, they warned the student who made noise. 
The interviewees stated that there were many factors which were out of the teachers' control. Those factors were the readiness of the students, students' personal problems, and technical problems. They also stated that content and materials influenced effectiveness of the instruction. Lack of readiness of the students to the new topic extended the time which was allocated for different activities. Some interviewees reported that they observed the mentor teachers reflected their private problems to the student. Those interviewees believed that a teacher should not reflect his/her own problems to the class. The interviewees also emphasized that in any technical problem the classroom management became much more difficult especially in lower grades.

\section{Suggestions for ITT}

The interviewees complained that many courses among ITT courses lacked practical activities and most lectures were limited with PowerPoint presentations. They stated that the courses that include practical applications of the instructional theories suffered seriously from time limitations. Moreover, according to interviewees, they were not pleased with the language of the courses since the education language was English in the university. Except one interviewee, all of them pointed out that they would be a teacher in their countries and there was no need to take their education in English. Also, they criticized that they could not learn Turkish vocabulary of many English terms and they used them incorrectly when they tried to translate them into Turkish. Seven out of eight interviewees (since 1 of them from a different country) stated that these courses should be given in Turkish. Also, they said that all of the learning and instructional theories stemmed from a different culture and the practical examples of these theories also referred to the schools in different cultures. During the educational courses, the practical examples of these theories should be given by considering Turkish context.

The interviewees suggested that some courses should be removed from ITTs' curriculum because they were not necessary. Three interviewees stated that in the first year of the university education, they went to elementary schools in order to observe mentor teachers in the classroom. Since they did not know anything about teaching and learning in that time, they were not aware of what they were observing. For that reason, in the educational programs, pre-service teachers should be equipped with background information about at least main issues in learning and teaching before they were sent to practice schools for observation. The practice courses in schools should be in the third and fourth years of the university education according to interviewees. All the interviewees stated that they should have had more experience in real context. They also noted that they needed experience in both private and public schools since these two school types were different than each other in terms of school policy, infrastructure, and students' profiles. Extracurricular activities should also be done according to the interviewees. One of students said that;

"Some student clubs visit schools in rural places and they spend a weekend with boarding school students, and this makes participants feel of 'making a difference', and I would love to feel it". 
The interviewees demanded more activities and practices that prepare them to the teaching profession. They stated that "School Experience" course included a range of activities such as observations of mentor teachers during instruction; observations of students in classroom and during breaks; interviews with mentor teachers and administrators; and teaching one of the subject matter from their field. They emphasized that all these activities provided them to realize the source of the some problems affecting effectiveness of the instruction. They also stated that their practice was different than theories and background knowledge. They emphasized that successful applications of these theories make possible for them to gain more experiences in teaching practice schools.

\section{Discussion and Conclusion}

This study focused on contributions of Initial Teacher Training Programs (ITT) to pre-service teachers' professional development. There are many implications to provide ITTs' reaching goals. Featherstone (1993) states "Pre-service teacher educators should ask themselves what they are doing to prepare their students look inward" (p.110). As advised by Featherstone (1993), the researchers aimed to enable pre-service teachers look inward by focusing on contributions of ITTs during their university years.

The study implied that ITT curriculum should provide pre-service teachers more contextual thinking. Thus, new strategies should be developed to provide these skills. It can be suggested that pre-service teachers to participate in real classroom environment more frequently to get used to real life contexts. To provide a realistic teaching experience, Korthagen (2004) proposes an "onion model" to define levels of pre-service teachers' background experiences. He suggests instructors creating an active learning environment, being a model, using direct instruction to train and coach, and changing students' beliefs by providing them awareness of existing situations. Results of this study showed that the pre-service teachers are in need of strategies to tackle with problems such as time management and classroom managements. Therefore, it can be argued that educators should design their courses to provide pre-service teachers a realistic values and affective skills by taking into account Korthagen (2004)'s suggestions.

As this study showed, the pre-service teachers tended to use their theoretical background in their teaching. They tried to match their teaching styles with certain theoretical framework, like Gagne's nine events. On the other hand, they were not ready for unexpected situations. Therefore, teacher education authorities should prepare the pre-service teachers according to unexpected events in class. The results of this study are parallel with Mellado's (1998) study which was conducted with four pre-service teachers. In this study also pre-service teachers showed stereotyped theoretical strategies that they learnt in their programs.

The present study also showed that the pre-service teachers had difficulties in applying their existing knowledge to real classroom. On the other hand, it should be noted that these pre-service teachers have just two class hours to teach although they observed a mentor teacher in a whole semester. In a few weeks, those pre-service teachers could have developed themselves in teaching and noticed their discrepancies between theoretical knowledge and real life situations if they were given chance to teach more than one. Moreover, the ITT curricula should evoke pre-service 
teachers' awareness on probable discipline problems and teaching strategies that they can use to tackle with these problems by taking into account students' characteristics.

Shortly, this qualitative study reveals the contextual issues influencing the practice of pre-service teachers. However, a further research is needed to understand the nationwide situation about the research subject. For the further/future research, the investigators plan to develop a survey by benefitting the findings of this study and collected data from pre-service teachers around the country.

\section{References}

Bogdan, R. C. \& Biklen, S. K. (1998). Qualitative research for education: An introduction to theory and methods. Boston, MA: Allyn and Bacon.

Collins, K.M.T., Onwuegbuzie, A. J., \& Jiao, Q. G. (2006). Prevalence of mixed-methods sampling designs in social science research. Evaluation and Research in Education, 19(2), 83-101.

Draper, J., O’Brien, J., \& Christie, F. (2004). First impressions: the new teacher induction arrangements in Scotland. Journal of In-Service Education, 30(2), 201-223.

Freiberg, H. J. (2002). Essential skills for new teachers. Educational Leadership, 59(6), 56-60.

Featherstone, H. (1993). Learning from the first years of classroom teaching: The journey in, the journey out. Teachers College Record, 95(1), 93-112.

Korthagen, F. A. J. \& Kessels, P. A. M. (1999). Linking theory and practice: Changing the pedagogy of teacher education. Educational Researcher, 28(4), 4-17.

Korthagen, F. A. J. (2004). In search of the essence of a good teacher: Towards a more holistic approach in teacher education. Teaching and Teacher Education, 20(1), 77-97

Loughran, J. \& Northfield, J. (1998). A framework for the development of self-study practice. In M. L. Hamilton (Ed), Reconceptualizing teaching practice, self-study in teacher education (pp.718). New York: Corwin.

Maxwell, J. A. (1996). Qualitative research design: An interactive approach. London: Sage.

Mellado, V. (1998). The classroom practice of preservice teachers and their conceptions of teaching and learning science. Science Teacher Education, 82(2), 197-214.

Miles M. B. \& Huberman A. M. (1984). Qualitative data analysis: A sourcebook of new methods. Newbury Park, CA: Sage.

Orungbemi, O. (2009). Awareness and use of teaching skills among primary school social studies teachers. Sustainable Human Development Review, 1(3), 127-138.

Smaldino, E. S., Lowther, L., D., \& Russell, D. J., (2007). Instructional technology and media for learning. New Jersey: Pearson/Prentice Hall.

Trigwell, K., Prosser, M., \& Waterhouse, F. (1999). Relations between teachers' approaches to teaching and students' approaches to learning. Higher Education,37(1), 57-70.

Willis, S. (2002). Creating a knowledge base for teaching. Educational Leadership, 59(6), 6-11. 
Correspondence: Hatice Sancar Tokmak, Instructor, Department of Computer Education and Instructional Technologies, Faculty of Education, Mersin University, Yenisehir Campus, Mersin, Turkey 